University of South Carolina

Scholar Commons

\title{
Life, Transferable: Questioning the Commodity-Based Approach to Transplantation Ethics
}

David Dillard-Wright

University of South Carolina - Aiken, davidd@usca.edu

Follow this and additional works at: https://scholarcommons.sc.edu/

aiken_history_politicalscience_philosophy_facpub

Part of the Philosophy Commons

\section{Publication Info}

Postprint version. Published in Society and Animals, Volume 20, Issue 2, 2012, pages 138-153.

(c) Society and Animals 2012

Dillard-Wright, D. B. (2012). Life, transferable: Questioning the commodity-based approach to transplantation ethics. Society \& Animals, 20(2), 138-153.

http://booksandjournals.brillonline.com/content/10.1163/156853009x393765

This Article is brought to you by the History, Political Science and Philosophy Department at Scholar Commons. It has been accepted for inclusion in Faculty Publications by an authorized administrator of Scholar Commons. For more information, please contact digres@mailbox.sc.edu. 
Life, Transferable: Questioning the Commodity-Based Approach

to Transplantation Ethics

\author{
David B. Dillard-Wright, Ph.D. \\ Assistant Professor of Philosophy \\ University of South Carolina, Aiken \\ Campus Box 30 \\ 471 University Parkway \\ Aiken, SC 29801 \\ davidd@usca.edu
}

\begin{abstract}
Some bioethicists have proposed a legalized market in human organs as a solution to transplant waiting lists and global poverty. Solutions to organ procurement problems that are solely market-based would unfairly shift the burdens of medical procedures onto developing nations. Market advocates base their claims on the understanding of organs as property, a position that should be problematized. Instrumentalizing people in this way is made part of the broader commodification of animals and the environment. Combating the market mentality requires a return to the holistic view of bioethics that led to the founding of the field.
\end{abstract}

Key Words: bioethics, transplantation, black market, organs, animal experimentation, xenotransplantation, donation

Commodities surround us and we inhabit them as much as they inhabit us. They are everywhere, and in part define who and what we are. It is as if our entire cosmos, the way we experience and understand our realities and lived existence in the world, is mediated through the base realities of sale and purchase. -Michael Watts 
To create the world means: immediately, without delay, reopening each possible struggle for a world, that is, for what must form the contrary of a global injustice against the background of a general equivalence. -Jean-Luc Nancy

The ancient Greek rites of the Thesmorphia brought fertility to crops, flocks, and humans alike. Later associated with Demeter and Persephone, the festival was originally represented by a sacred sow. An ur-goddess, divine before divinities, she symbolized new life and abundance with her profusion of teats (Murray 2002, p. 14-15). In contrast with previous associations of the pig with an indolent love of filth, the ancient rites now re-surface, secularized and sanitized, in a new form of life-giving, in laboratories and surgical theaters: so much depends on a slip of cartilage mined from a living being. Since the introduction of the porcine valve in the 1960's by Hancock Laboratories and its refinement in the now third-generation Medtronic version, many hundreds of thousands of cardiac implantations have been performed, and the procedure is considered "reliable and durable" (Hilal and Erikson, 1981; Munson, 2002; Lawton, Moazami, et al, 2008). In addition to these valve transplants, piglets can be purchased in a bag, embalmed in fluid, as a source and supply of anatomic knowledge; the very knowledge produced in this act of "sacrifice" will one day anatomize and systematize human bodies, make wholes into parts, enabling new generations of physicians and researchers. 
If today removing a pig heart valve and using it in place of a human one is a commonplace procedure, xenograft research promises to perhaps one day use pig kidneys, modified with human DNA, as a solution to organ procurement problems. In the meantime, though, (a theological delay here, waiting for the Parousia, the secular Second Coming, of a life free of suffering), a source of organs must be found if the thousands on waiting lists are to remain alive (Hauerwas, 1990). Once only food on a plate, the pig assumes, in part, a place in the human organism. In transgenic research, its DNA, too, becomes human, in an attempt to make this close biological relative of humans even closer. Transplant medicine sutures worlds, species, people together, splices flesh to flesh, makes one animal partially another. As far as medicine has advanced, though, doctors cannot heal failed organs, and they cannot produce life out of nothing.

The extraction of tissue from pigs has its parallel in extractions of organs from people, in a series of different source pools: cadaveric organs, living donations, and the black market. Animal experimentation and medicine enables the transfer of organs, of life, from one human body to another. Running on a parallel course with world labor and commodity markets, medicine joins in the process of natural resource extraction, exacting a living toll from the bodies of human and non-human animals. "The biotech revolution...is the result of a whole series of legislative and regulatory measures designed to relocate economic production at the genetic, microbial, and cellular level so that life becomes, literally, annexed within capitalist modes of accumulation" (Cooper, 2008, p. 19). "Taking life" need not mean killing: it can refer to the transfer of one organism's cells, tissue, genome or organs to another. A global network of such transfers now exists 
in which various goods - money, health, and the organs themselves - are transferred from less privileged persons to more privileged ones. The organ market moves life disproportionally from bodies of color to white bodies, from women to men, from the developing to the developed nations, and finally, from non-humans to humans (Alexander et al, 1998; Rothfield, 1995). The extraction and redistribution of life falls along the lines of the gender / race / species hierarchies identified by the feminist care tradition (Adams, 2007, pp. 30-32). The outsourcing seen in commodity markets has its parallel in the organs "market": the same Pakistani laborers making soccer balls and running shoes for transnational corporations might also be coerced into selling a kidney or having a kidney stolen (the difference between the two is rather marginal: see below).

Much has been written in the past about the ethics of transplantation, both on the human-to-human (allotransplantation), and the much more theoretical animal-to-human (xenotransplantation) side of biotechnology debates. This project differs from previous explorations of transplant medicine in its insistence on thinking these two sides of ethics together, by asking how the instrumentalization of animals makes possible the instrumentalization of humans and vice versa. The paper closes by offering some reflections on how bioethics can address proposed markets in human organs and gives some direction for the future of the discipline.

\section{Black Markets and Bioethics}

The idea of an illegal kidney surgery conjures up similar images as back-alley abortions: perhaps taking place in a warehouse somewhere with a swinging light bulb 
overhead and a tray of rusty instruments. It is true that such surgeries are more risky than legal transplant surgeries in the event of an emergency, but they normally take place in hospitals, under cover of night, using the exact same techniques and equipment used in legal surgeries. The physician performing the surgery has probably performed many such surgeries and may be quite competent at the job. The patient will receive the exact same aftercare in his or her country of origin as would have taken place in the event of a legal surgery.

Countries that serve as sources for illicit organs (stolen organs as well as those harvested through cash payments) include places as diverse as China, Brazil, India, Pakistan, Russia, Moldova, and Romania (among others) with most recipients of organs coming from the United States, Europe, and Israel (Goyal et al, 2002; Goodwin 2006, p. 11; Rohter, 2004; Scheper-Hughes, 2005). Indeed, "[t]here is now no country that is unaffected in some way or other by this trade," (Berthillier, 2003, p. 161). Surgical facilities in Eastern Europe, Turkey, South Africa, and South America, and other countries host the illegal surgeries, with surgeons in Eastern Europe making “a 'mere' 400,000 to 500,000 euros [on] four to five operations being carried out ... in one night," of which donors can expect to see two or three thousand or perhaps even less (Berthillier 2003, 165). Procurement of organs has ties to organized crime, and the problem is exacerbated by the fact that a crackdown in one country simply leads "recruiters" to go to another unstable part of the world. In this respect, the market in human organs resembles the emerging human slavery problem and the legal, though exploitative international labor market. Regulation in one country simply shifts the burden elsewhere, and few protections exist to curtail the problem on an international level. In 
most parts of the world, paying for human organs is already illegal, but this does not stop the trade from taking place. Arrests or manhunts for surgeons and "donors" have taken place, notably Israeli kidney broker Ilan Peri, who was charged with tax evasion, and the Interpol manhunt for Amit Kumar, a trafficker based in Calgary and harvesting organs in India (Rohter, 2004; Yelaja 2008; Nanda 2008).

To my knowledge, no medical tourists or aftercare physicians have ever been arrested or otherwise punished for participation in this trade. Physicians in developed countries operate according to an unofficial “don't ask, don't tell” policy in which they either encourage their patients to procure organs overseas or remain willfully ignorant of the source of the organ (Scheper-Hughes, 2002, 65). Hence clinics and hospitals all over the world receive part of their profits or operating costs from the illegal trade in organs: organ brokers act as unofficial agents of the medical establishment. This trend mirrors sweatshop labor, in which the contractor can always claim ignorance of the actions of the subcontractors. Similarly, the anti-rejection drugs used in illegal procedures amount to a boon for the bottom line of pharmaceutical manufacturers: the balance sheet doesn't care about the origin of the organ in question. Though unintentional, this amounts to a form of medical outsourcing in which mainstream medicine hands over its more ethically onerous tasks, creating plausible deniability.

Very few studies have been made in order to determine the long-term effects of organ donation on the poor in third world countries. The existing information comes from the Goyal et al study in Chennai, India published in the Journal of the American Medical Association (JAMA) and the ethnographic studies published by anthropologist Nancy Scheper-Hughes, founder of Organ Watch at the University of California- 
Berkeley. The JAMA study found that nearly all of the study participants (96\%) had sold a kidney to pay off debts and that the average amount received was $\$ 1070$ (Goyal, 2002, p. 1589). The decision to sell an organ amounts to economic "conscription" resulting from the heightened disparities of neoliberal globalization (Rajan, 2006, p. 80). At an average elapsed time of 6 years after the nephrectomy, most families reported worsened economic conditions since the surgery, with annual incomes dropping from " $\$ 660$ at the time of nephrectomy to $\$ 420$ at the time of the survey, a decrease of one third" (Goyal et al, 2002, pp. 1590-1591). Half of the participants complained of pain at the surgery site and a third said that they suffered from ongoing back pain (p. 1591).

While some bioethicists may characterize a kidney as "redundant" or a "spare part," using the language of "vendor" or "seller" to refer to victims of organ traders (Taylor, 2005; Wilkinson, 2003; Cherry, 2005; Baron, 2006), these pro-market perspectives, though perhaps not blindly, dogmatically pro-market (as in neo-liberalism), ignore the realities faced by many kidney sellers around the world:

Organs Watch has found that living kidney donors from shantytowns, inner cities, or prisons face extraordinary threats to their health and personal safety through violence, accidents and infectious disease that can all too readily compromise their remaining kidney. As the use of live kidney donors has moved from the industrialized West, where it takes place among kin and under highly privileged circumstances, to areas of high risk in the developing world, transplant surgeons [and, I would add, aftercare physicians, pharmaceutical companies, and others in Western 
nations] have become complicit in the needless suffering of a hidden population (Scheper-Hughes, 2002, p. 77).

Here another asymmetry asserts itself, in that organ recipients have widely available aftercare, where organ donors from third world countries do not have access to care. Scheper-Hughes has also found that social stigma attaches itself to organ sales. The predominately young men who sell organs to support their families find themselves unable to marry or find a job because of a perception that they are "weak" and incapable (Scheper-Hughes, 2002, p. 76).

No serious bioethicists argue that the current black market in human organs can be morally justified, but many do argue that a legalized and regulated market would be able to set a fair price, one that could compensate sellers for the many trials that they endure both during and after the donation process. Such a solution must not be dismissed out of hand, but a large degree of suspicion should be applied to market-based solutions. The mere fact of cash changing hands does not excuse or exempt organ recipients and other stakeholders from caring about the people who served as sources for those organs. Asking the world's poor to bear the brunt of first-world medical conditions is an unconscionable exacerbation of an already unjust set of global relations. Systematic wrongs cannot be addressed by piecemeal solutions like organ sales, and advocating for organ sales is a disingenuous form of concern for the poor arising from the ulterior motive of increasing the supply of organs available for first-world people. Such motives instrumentalize the poor, "turning their suffering into an opportunity" (Scheper-Hughes, 2002, p. 78). The "quantification of suffering" assumed in a recent spate of bioethics 
books on transplants (e.g. Taylor, 2005; Wilkinson, 2003; Cherry, 2005; Baron, 2006)

misses this suffering by making it into a unit in an equation of benefits and losses: this distributive paradigm must itself be questioned before people can begin to care about marginalized humans and animal subjects (Donovan, 2007, 64).

If the "supply side" has been distorted by this distributive paradigm, the recipient side also has been manipulated by the technoscientific insistence on the extension of life. Transplant lists have been artificially inflated by a consumerist attitude towards medicine that views any and all conditions as treatable, and now new classes of patients are increasingly considered eligible for transplantation, including "those over 70 years, infants, those with hepatitis C and HIV seropositivity, and those proven to be immunilogically prone to organ rejection" (Scheper-Hughes, 2002, p. 66). This new category of patients does not stand to benefit much from transplantation because their ages and medical conditions make rejection likely: this is not a matter of discriminating among patients but simply taking into account the viability of the procedure. As transplant technology advances, this demand from a broadened patient pool will likely increase, along with the persistent lack of regard for those who must bear the cost of these surgeries. Meanwhile, viable organs around the world go unused because the infrastructure to extract them does not exist (Scheper-Hughes, 2002, p. 67). Making technology available to more hospitals worldwide would help to increase the supply of organs, but this solution requires more work than allowing the black market to flourish. Scheper-Hughes notes that many available organs worldwide rot in dumpsters because the hospitals do not have access to the technology to preserve them (2002). While I do not think that those who need organs should just be allowed to die, it does make sense to 
maximize other sources of organs before mining the bodies of the world's poor, since they already must bear the brunt of first-world resource extraction and the legacy of colonialism. As if it weren't already enough that land and water are increasingly privatized and that labor and environmental standards are gutted by the trend towards globalization, the world's most vulnerable are now asked to surrender their very bodies so that the world's elite can have longer, more comfortable lives. While I might be accused of a lack of compassion for those suffering from medical difficulties, such compassion is misplaced if its exercise comes at the expense of vulnerable others.

\section{Questioning the Property Paradigm}

The call for a legalized market in human organs among many bioethicists in the last decade can be explained by the stance that these philosophers take towards the body, non-human animals, and the natural world. A subtle act of exclusion is either assumed in these texts or treated in a cursory fashion. This act of exclusion, often one of the most important claims made in such texts, goes unanalyzed or is treated as a merely practical consideration. A few examples help to clarify what I mean when I say "act of exclusion." Mark Cherry takes for granted the Kantian dictum that humans have no direct duties to animals or the natural world:

Animals and things that do not possess the requisite cognitive capacities cannot be intersubjectively experienced as persons and, therefore, cannot be affirmed as such within the context of a general secular morality... Indeed, once beings lose the cognitive capacities that sustain personhood, 
they become beings, if not things, which have the character of being former persons $(2005$, p. 22).

Without taking into account investigations into the consciousness of animals (most of them secular moral accounts) that have been made since 1797 when Kant first made this exclusion, Cherry goes on to emphasize that only humans having the "requisite cognitive capacities" should be considered in calculations of the "costs and benefits of various uses of one's body and property” (2005, p. 23). Not recognizing non-humans as having interests creates a planet conceived only as actual or potential property, without a wellbeing of its own.

Perhaps not surprisingly, the body itself comes to fall under the purview of property, since it shares features with all of the other things that Cherry regards as interchangeable commodities. The (optimally functioning, human) brain alone deserves protection according to Cherry, who describes all parts of the body except the brain as replaceable and the kidneys as "redundant" (2005, pp. 27, 28, 33). Even if it were possible to transplant every part of the body except the brain, it is disingenuous and arbitrary to suggest that only the brain counts as a seat of subjectivity or personhood. All sorts of factors play a part in the constitution of personhood, factors which cannot simply be detached from lived embodiment. We regard bodies, even dead bodies, as persons in some sense and "driving a conceptual wedge between persons and their body parts," as Cherry advocates, does not seem like a good way to guarantee that persons are respected (2005, p. 28). Brains themselves do not amount to much without the complex corporal and inter-corporal relationships that make them into sites of personality and 
individuation. These relationships are short-circuited or ignored by the distributive paradigm, which views organs as units or capital to be bought and sold.

Conceiving of organs as property to be bought and sold produces an artificial detachment that does not accord with the experience of many transplant patients on both the "donor" and "recipient" ends of the procedure. Recipients may develop an identification with the donor and find themselves incorporating not only a new organ but aspects of the donor's personality along with the transplanted tissue.

Some recipients may have difficulty accepting the new graft as 'part of self' or may feel that they have inherited 'the donor's characteristics with the transplant'... Reports of this phenomenon are usually from the heart transplant programmes although several patients in our kidney programme have reported 'perceived personality changes' (Franklin, 2003, pp. 58-59).

Some transplant patients may find themselves drawn to new foods that they identify with the donor's tastes, or they may become extremely curious about the details of the donor's life (Franklin, 2003, pp. 58-59). Other recipients may develop a kind of dread of the new organ and find themselves not wanting to know anything at all about the donor. The organ comes with a feeling of an infinite debt that cannot be repaid, and the response of dissociation helps the recipient to avoid this uncomfortable feeling. Both the response of identification and the response of dissociation acknowledge that the organ carries personhood and that the donor has given not just an organ but has given something of his or her self. The organ comes with an "emotional investment" that makes itself felt in the recipient (Rothfield 1995, p. 194). Failing to recognize this phenomenon or dismissing it 
as "psychological" denies the organic unity of body and mind, a unity which donor and recipient struggle to recover after the surgery. Even if the surgery takes only a few hours, the sense of bodily dysphoria may last for years.

In addition to the personality effects, many recipients will experience other "body image problems" related to the surgery and immuno-suppressive drugs

Corticosteroids (prednisolone) may cause acne and an abnormally round face and protruding abdomen. Patients taking ciclosporin often have mild tremors and swollen and overgrown gums (gingival hyperplasia).

Ciclosporin has recently been replaced by new drugs that have less severe effects on the body, but studies suggest that many transplant recipients still report body image with subsequent lower self-esteem and feelings of inferiority or of 'being altered or damaged' (Franklin, 2003, p. 58).

The recipient's whole body comes to seem unfamiliar after the surgery and not just the foreign organ. The meaning-content of the body cannot be divorced from its physical characteristics, as evidenced by the recipient's identity struggles after receiving the organ. While in medicine it may be useful to describe the body as a set of interlocking systems or molecular interdependencies, this should not obscure the body's role a social signifier. Conceiving of the body as a mechanistic assemblage of exchangeable parts misses the ideal aspects of embodiment tied to carnal locations.

One might raise, for the sake of argument, that reports of bodily dysphoria have been overstated or that such problems can be overcome through therapy and perhaps additional medication. Such problems associated with transplantation would also apply 
to other forms of donation, and not just market-based models. Transplantation

proponents rightly raise the issue that surely being alive with some sense of bodily dysphoria should be preferred to dying or being chronically ill. Once transplantation technologies become available, it seems naïve to think that people would just accept death because someone might suffer on the other end of the transplant chain. I only wish to point out that dysphoria reveals the fabric of relations that characterizes our relationships with our own bodies and with the bodies of others. Merleau-Ponty divides thought about the body into a tripartite structure of relationship with oneself, relationship with the world, and relationship with others, all of which must be taken simultaneously when considering the meanings arising from lived engagement with the world (1968, p. 145). As the transplant cuts across these sets of relations, care must be taken to stitch together not only the living flesh, but also the "flesh" of social relations that give bodies and organs their meaning-content. In order to bolster social relationships, a one-time cash payment would not suffice. Any market-based transplantation "solution" must be a small piece of a larger picture that allows donors access to healthcare, education, and, in short, a better way of life. Above all, bioethicists, patients, physicians, and researchers must relate to organ donors as people, with whom we are existentially, and not merely commercially related, rather than as sources and suppliers. Cora Diamond expresses this idea when it comes to non-human animals well, that we might better think of ourselves as being "in the same boat" with them rather than merely biologically related, as "company" and not commodity (1974, p. 474).

\section{"Saving" through "Sacrifice"}


"Life saving" actually codes for "life extension" and even "lifestyle enhancement" in many bioethics texts. The cloak of 'saving lives' (Which lives? At what cost? To whom?) creates a blind spot that protects biomedicine from outside questioning. The "irresistible themes of progress," the promise of life extension, prevention of disease, and even national interests ("American preeminence" in bioscience), prevent any real inquiry into transplantation science (Hanson, 1995). Meanwhile, the business of medicine externalizes its costs by shifting its burden onto the environment, animals, and the global poor, profiting at the expense of others, including the patients that it serves. As somatic ethicist Ralph Acampora puts it, "The labor and lives of rats and mice [here I can add pigs, baboons, and other research animals] are [...] referred to as 'sacrifices' for the restoration and uplift of human health; thus, these animals come to acquire moral significance through the backdoor of crypto-theistichumanism" $(2006,102)$. In the meantime, society will accept tremendous injustices and untold human and animal suffering, so long as someone assures them that human lives will (eventually) be saved. A connection can be traced between the slum dweller in Brazil who attempts to escape poverty by selling a kidney, the pharmaceutical companies that manufacture anti-rejection drugs, the pigs and other animals 'sacrificed' in order to develop those drugs, and the insurance companies and clinics who make their profits through such procedures. The pigs, baboons, monkeys, rabbits, rats, and mice involved in developing transplantation technology, currently only mentioned in the sub-discipline of "research ethics" should be brought to bear on the main issue of transplantation itself. 
The disappearance of animals from the organs debate occurs for the same reason that the effects on donors or sellers are minimized: bringing the instrumentalization of animals and humans into full view would mean subjecting biomedicine to a more rigorous critique than these thinkers are willing to make. The everyday disregard for the depredations suffered by animals carries over into a disregard for the suffering of lessprivileged humans.

Xenotransplantation (transplantation from a member of one species to a member of another species) and allotransplantation (transplantation from two members of the same species) are two sides of the same coin. Xenotransplantation experiments on pigs and baboons figure into the human transplant system, because the instrumentalization of these animals leads to the development of new drugs and genetic procedures to make the whole process more efficient, whether or not these experiments ever lead to an inexhaustible supply of genetically tailored pig organs. Nor is it the case that human-tohuman transplants do not involve the use of animals, since a survey of some prevalent anti-rejection drugs indicates that a wide range of animals are used in the development process. To take just four of the many anti-rejection drugs on the market, the list of animal subjects used in testing reads like the Chinese zodiac: Atgam ${ }^{\circledR}$ (Pfizer), which is actually derived from horse globulin, went through animal trials on rhesus monkeys and croo monkeys; Rapamune ${ }^{\circledR}$ (Wyeth) was tested on "rats, pigs, and / or primates," CellCept (Roche) was tested through primate and rat allografts, and the oldest and most commonly used, Cyclosporine or Neoral (Novartis) was tested on rats, mice, rabbits, and Chinese hamsters. I bring this information forward not to make the animal rights argument against lab testing of animals, but to understand the inputs that go into the 
pharmacological system, inputs which are normally buried in product disclosure statements difficult for the average consumer to understand. It would be incorrect to suppose that a human-to-human graft does not involve any animal inputs, since the antirejection medicines are either animal-derived, animal-tested, or both.

Like laboratory animals, humans occasioning transplant technology are also caught within its grasp, made part of the technological process, co-evolving with it. Humans occasion technology but they should never think that occasioning somehow equals mastery (Heidegger, 1977). In fact, the illusion of a mastery over technology is precisely its danger: inasmuch as people think that they can master technology, they fall into its trap. Technology reveals something that already underlies it and does not create something entirely new: to use non-Heideggerian language, technology is something nature does through human beings. Technology challenges nature to bring forth its hidden potential, but this same challenging reverberates onto human beings (Heidegger, 1977, pp. 14-16). As human beings order the universe, they are ordered themselves, a process that Heidegger calls "Enframing."

Inasmuch as humans do not recognize that they, too, are enframed or challenged through the process of technology, they are doomed to keep trying to master it, which will always fail (the danger). If, however, they can see this process for what it is, they can recognize their own part in the process and avoid the never-ending drive towards mastery (the saving power). Inasmuch as humans think that technological mastery is destiny, they are doomed to become cogs in the machine, so to speak. Heidegger puts this more starkly in "The Turning": 
If the essence, the coming to presence, of technology, Enframing as the danger within Being, is Being itself, then technology will never allow itself to be mastered, either positively or negatively, by a human doing founded merely on itself. Technology, whose essence is Being itself, will never allow itself to be overcome by men. That would mean, after all, that man was the master of Being (1977, p. 38, emphasis added).

The Turning that needs to happen is the recognition that humans do not merely make technological objects; they are also made by them, objectified by them. The saving power occurs when "man" has the insight that this is taking place, thereby seeing the essence of the human clearly for the first time. The saving power does not stop the process from happening: it just recognizes the process of "destining" for what it is. Heidegger steers a course between the two extremes of technological positivism and Luddite romanticism: he wants people to see clearly what happens when they think they are taking the reins of the objects they "create."

People, animals, and technology, all co-actors in the formation of new biomedicine, all enframed by the process of technological unfolding, become new entities in this process. Nature-culture, too, is transformed in order to feed this new system: the very definitions of species tremble under the prospects of hybrid humans and hybrid animals. Hannah Arendt's Marxist reflections aptly state the situation:

Man, insofar as he is homo faber [the human who works or makes], instrumentalizes, and his instrumentalization implies a degradation of all things into means, their loss of intrinsic and independent value, so that 
eventually not only the objects of fabrication but also 'the earth in general and all forces of nature,' which clearly came into being without the help of man and have an existence independent of the world, lose their 'value because they do not present the reification which comes from work"” (Arendt, 1998, p. 156).

The organ comes to have value once it is placed on the open market, just as the pig becomes valuable as its DNA is tailored to meet human specifications. Life itself is not enough, doesn't count, unless it has been submitted to the enframing of technological alteration and given a dollar value. Biotechnology represents the ultimate extension of Homo faber's power: no longer is it enough to fit the worker to the machine, to manage time according to the dictates of production, to mold the earth according to the exigencies of commerce. Now humanity remakes itself and other creatures in order to ensure that technological destining continues. The outcome of this process, its costs, by no means spread themselves evenly across human society and the extra-human world. "Man," an appropriately anonymous subject, continues the triumphal march of progress, while animal and human others are liquidated, their bodies fungible resources subject to market control.

Organ transplantation, in each of its manifestations, is marked by several disappearances. The lab animal, hidden in the "black box" of scientific research, rarely becomes the focus of public observation, disappearing into its tissues and molecules (Latour, 1987, pp. 1-17). Just as this animal is hidden away, unvalued, human donors face the same fate. In the black market (and this problem would also occur in a 
legalized market), the donor disappears, somewhere half a world away, never becomes real for those involved in the process. Contesting the inequities of biomedicine requires re-examining the neglected content, bringing the less privileged others back into view. This requires action, in Hannah Arendt's sense of the term, because the edifice of civilization deliberately hides these human and extra-human others from view. In order to make ourselves well, we have to know and act on behalf of the others with whom we always already engage on the level of exchange.

\section{Recalling Bioethics to its Founding Impulses}

With Richard Twine (2007; 2010), I argue here for a "less enclosed bioethics," capable of considering not only the instrumental good for humans (or for some humans over others) in a particular decision-making context (medical, agricultural, pharmaceutical, or some combination thereof), but to take into account the interplay of society and environment, human and animal, global poor and global elite. As Twine writes, "[t]he narrowing of bioethics to medical ethics, or sometimes 'biomedical' ethics, represents an unreflexive anthropocentric conception of the 'bio' in bioethics, which brackets out environmental and animal ethics and tends to downplay socio-political, socio-economic and ecological inputs in human health" (2007). The "narrowing" of bioethics drives the agenda to subsume life on earth under the aegis of free-market capitalism: in a vicious oversimplification, anthropocentric bioethics provides its own justifications by ignoring the good of animals, the environment, and the less privileged humans who have disproportionately borne the risk in clinical trials (Cooper, 2011). 
Hopefully bioethics will become, as the name implies, an ethics of all life, will become more utilitarian, in the classical sense of maximizing the good of all creatures. Perhaps Martha Nussbaum's concept of “flourishing” can help here (2001). Flourishing requires more than just averting death or extending life: it requires a passionate commitment to the others who co-constitute us as persons, who share in the networks of mutuality that make us human (Twine 2001). Compassionate engagement will not stop technological enframing, but it might change the way in which humans co-evolve with technology, with each other, and with other species. The human world is impoverished by the disappearances I have named above, and by opening the circle of concern, people choose a better future for themselves, other creatures, and the earth.

This call to bioethics to practice not just a crude calculus of benefits and rewards but an ethic of caring for all species — indeed all individuals—actually returns bioethics to its founding impulse as an evolutionary ethic of all species (Jonsen et al, 1993). Founding figures like Van Rensselaer Potter and Michael Fox envisioned an ethics that would connect environmental concerns with new medical technologies and human rights. They criticized the portioning of ethics into a variety of subfields that allowed for exploitation:

This disconnectedness [of objectifying other creatures] becomes generalized in sociopathic, biopathic, and zoopathic behaviors that collectively lead to the destruction of Earth. Collective biopathic behavior is exemplified by industrialism's destructiveness of the natural environment and by those values that place material gain over ecological sustainability, and that inevitably lead to economic instability and environmental disease (Fox, 1989, p. 41). 
Fox here summarizes what I have said in the above analysis of the organs trade: that the degradation of Earth, the lack of respect for human rights, and a disregard for non-human life are all related and ultimately trade short-term economic gain for long-term devastation. The only remedy for this "false reductionistic and mechanistic orientation" is a return to a "reverential attitude of heart and mind" (Fox, 1989, p. 41). Fostering this "reverential attitude" must become the primary task of bioethics, as it was at the field's founding. Markets may be able to accomplish amazing transfers of goods and information, but they don't innately have any caring properties. Fostering care requires all actors within the system to claim responsibility for all of the inputs into that system, refusing to outsource harms to less valued persons and species. Debates about organs markets must take all factors into consideration, and not just a narrow calculus of the exchange of benefits. 


\section{References}

Acampora, R. (2006). Corporal Compassion: Animal Ethics and Philosophy of Body.

Pittsburgh: University of Pittsburgh Press.

Adams, C. (2007). “The War on Compassion.” In J. Donovan and C. Adams, (Eds.) The Feminist Care Tradition in Animal Ethics. New York: Columbia University Press. 21-36.

Alexander, G. \& Sehgal, A (1998). "Barriers to Cadaveric Renal Transplantation Among Blacks, Women, and the Poor.” Journal of the American Medical Association, 280 (13). 1148-1152.

Arendt, H. (1998). The Human Condition. $2^{\text {nd }}$ Ed. Chicago: University of Chicago Press.

Baron, J. (2006). Against Bioethics. Cambridge, MA: MIT Press.

Berthillier, C. (2003). "The trade in organs in Europe.” In Council of Europe Publishing, (Eds.) Ethical Eye: Transplants. Strasbourg: Council of Europe. 161-167.

Cherry, M. (2005). Kidney for Sale By Owner: Human Organs, Transplantation, and the Market. Washington, DC: Georgetown University Press.

Cooper, M. (2008). Life as Surplus: Biotechnology and Capitalism in the Neoliberal Era. Seattle: University of Washington Press.

--- (2011). "Trial By Accident: Tort law, industrial risks and the history of medical experimentation.” Journal of Cultural Economy, 4 (1). 81-96.

Cüer, P. (2003) “Can some transplantations affect identity?” In Council of Europe Publishing, (Eds.) Ethical Eye: Transplants. Strasbourg: Council of Europe. 6368. 
Hauerwas, S. (1990). God, Medicine, and Suffering. Grand Rapids, MI: Eerdmans, 1990.

Jonsen, A. \& Alexander, S. et al, (1993). "Special Supplement: The Birth of Bioethics." Hastings Center Report 23 (6). 1-16.

Diamond, C. (1974). “Eating Meat and Eating People.” Philosophy 53 (206). 465-479.

Donovan, J. “Animal Rights and Feminist Theory.”. In J. Donovan and C. Adams, (Eds.) The Feminist Care Tradition in Animal Ethics. New York: Columbia University Press. 58-86.

Fox, M. (1989). “Contested Terrain: Beastly Questions.” Hastings Center Report, 19 (2). 39-42.

Franklin, P. (2003). “The recipient's perspective.” In Council of Europe Publishing, (Eds.) Ethical Eye: Transplants. Strasbourg: Council of Europe. 51-62.

Goodwin, M. (2006). Black Markets: the Supply and Demand of Body Parts. Cambridge: Cambridge University Press.

Hanson, M. (1999). "The Seductive Sirens of Medical Progress: The Case of Xenotransplantation.” The Hastings Center Report, 25 (5). 5-6.

Hanson, M., L.-M. Russow, \& C. McCarthy. (1999) “Case Study: A Xenotransplantation Protocol." Hastings Center Report 39 (6). 22-25.

Heidegger, M. (1977). W. Lovitt (Trans.) The Question Concerning Technology and Other Essay. New York, Harper.

Hilal, S. \& Erikson, W. (1981) "Matching Supplies to Save Lives: Linear Programming the Production of Heart Valves." Interfaces, 11 (6). 41-56. 
Latour, B. (1987). Science in Action: How to Follow Scientists and Engineers through Society. Cambridge, MA: Harvard University Press.

Lawton, J.S., Moazami, N., et al. (2009). "Early Stenosis of Medtronic Mosaic Porcine Valves in the Aortic Position." Journal of Thoracic and Cardiovascular Surgery 137 (June). 1556-1557.

Lippit, A. (2000). Electric Animal: Toward a Rhetoric of Wildlife. Minneapolis: University of Minnesota Press.

Merleau-Ponty, M. (1968). The Visible and the Invisible. Evanston: Northwestern University Press.

Munson, R. (2002). Raising the Dead: Organ Transplants, Ethics, and Society. Oxford: Oxford University Press.

Nanda, H. “Inside Kidney Kingpin’s Mansion.” Hindustan Times. February 5, 2008. Accessed online June 24, 2008. http://www.hindustantimes.com

Nussbaum, M. (2001). Women and Human Development: The Capabilities Approach. Cambridge: Cambridge University Press.

Potter, V. R. (1971). Bioethics: Bridge to the Future. Englewood Cliffs, NJ: PrenticeHall.

Rajan, K. S. (2006). Biocapital: The Constitution of Postgenomic Life. Durham, NC: Duke University Press.

Rose, N. (2007). The Politics of Life Itself: Biomedicine, Power, and Subjectivity in the Twenty-First Century. Princeton: Princeton University Press. 
Rothfield, P. (1995). “Bodies and Subjects: Medical Ethics and Feminism.” In P. Komesaroff (Ed.). Troubled Bodies: Critical Perspectives on Postmodernism, Medical Ethics, and the Body. Durham, NC: Duke University Press. 168-201.

Scheper-Hughes, N. (2002). "The Ends of the Body: Commodity Fetishism and the Global Traffic in Human Organs." SAIS Review, 22 (1). 61-79

---. (2005) "Organs Without Borders." Foreign Policy, 146 (1). 26-27.

---. (2006). "Biopiracy and the Global Quest for Human Organs." NACLA Report on the Americas 39 (5). 14-21.

---. (2007). “The Tyranny of the Gift: Sacrificial Violence in Living Donor Transplants." American Journal of Transplantation, 7. 507-511.

Taylor, J. (2005). Stakes and Kidneys: Why Markets in Human Body Parts are Morally Imperative. Burlington, Vermont: Ashgate.

Twine, R. (2001). "Ma(r)king Essence-Ecofeminism and Embodiment.” Ethics and the Environment, 6 (2). 31-58.

---. (2007). "Thinking across species—a critical bioethics approach to enhancement." Theoretical Medical Bioethics, 28. 509-523.

---. (2010). Animals as Biotechnology: Ethics, Sustainability, and Critical Animal Studies. London: Earthscan.

Uncaged UK. (2000). "Diaries of Despair: The Secret History of Pig-to-Primate Organ Transplants." www.xenodiaries.org.

Wilkinson, S. (2003). Bodies for Sale: Ethics and Exploitation in the Human Body Trade. London: Routledge. 
Wilson, E. O. (1993). "Biophilia and the Conservation Ethic.” In S. Kellert \& E. Wilson (Eds.) The Biophilia Hypothesis. Washington, D.C: Island Press.

---- (2006). The Creation: An Appeal to Save Life on Earth. New York: Norton.

Yelaja, P. (2008). "Patients Blamed in Kidney Scam: 'Selfish' people seeking transplants bargain down price, medical tourism agent says." Toronto Star. February 5, 2008. Accessed online June 24, 2008.

http://www.thestar.com/News/GTA/article/300437 